\title{
INCREASING THE COMPETITIVE POTENTIAL OF AGRICULTURAL HOLDINGS THROUGH COLLABORATION AND COOPERATION
}

\author{
J. Doitchinova ${ }^{1 *}$, R. Terziyska ${ }^{2}$, A. Petrovic ${ }^{3}$, M. Colic ${ }^{3}$ \\ ${ }^{1}$ Trakia University, Stara Zagora, Bulgaria \\ ${ }^{2}$ University of National and World Economy, Sofia, Bulgaria \\ ${ }^{3}$ ZiP-Centar Mladih Enterprise \& Employment Centre, Pirot, Serbia
}

\begin{abstract}
The high relative share of small farms in Bulgaria and Serbia and their low incomes, high unemployment, and population decline in rural areas are among the reasons for seeking forms of coordination, co-operation and cooperatives for farmers. The purpose of the report is to analyze the problems of small farms and the opportunities for increasing their competitive potential through participation in network structures. The subject of the report is the benefits for farmers in Bulgaria and Serbia from participating in different network structures, as well as the difficulties in their creation and functioning. The article contains four parts. The first one is Main characteristics and trends of agricultural development in Bulgaria and Serbia; the second one - structures, characteristics and problems of agricultural holdings; the third one - Problems of setting up and functioning of network structures of small farmers; and the last one - Opportunities, guidelines and recommendations. The research in this study is based on the results of the Census of Agriculture 2012 in Serbia and on the information from the Department of Agrostatistics of the Bulgarian Ministry of Agriculture and Food, Agrostatistics Department (2013), as well as official data of EUROSTAT for the EU 28.
\end{abstract}

Key words: agricultural holdings, collaboration, cooperation, network structure

\section{INTRODUCTION}

Serbia has a population of 7.076 million (2016) across nearly 78,000 square kilometres of territory. The total area of Bulgaria is 110, 994 square kilometres according to the United Nations Statistics Division. The population of Bulgaria totals $7.080 \mathrm{mln}$. people (2016). The rural population accounts for 39 per cent of those people in Bulgaria and for 40.6 per cent in Serbia.

Agricultural land covers a dominant part of the total land territory of the Republic of Serbia and the Republic of Bulgaria and represents one of the most important natural resources that determine overall and particular rural development. Land as the objective condition of agricultural production and operation of any form of family farms is both a means and object of labour.

Agriculture is a traditional sector in the economy of both countries. Over the last decades, there have been various reforms,

\footnotetext{
*Correspondence to: Julia Doitchinova, Trakia University, Stara Zagora, Bulgaria, Phone + 359888711815; E-mail: juliadoj@abv.bg
}

mainly driven by the introduction of common agricultural policy approaches and mechanisms within the framework of their national agrarian policies, even more in Bulgaria was carried out comprehensive land reform (1992-1999). As a result of these changes, the current organizational structure was formed. The high relative share of small farms in Bulgaria and Serbia and their low incomes, high unemployment, and population decline in rural areas are among the reasons for seeking forms of co-ordination, co-operation and cooperatives for farmers.

The purpose of the paper is to analyze the problems of small farms and the opportunities for increasing their competitive potential through participation in network structures. The subject of the paper is the benefits for farmers in Bulgaria and Serbia from participating in different network structures, as well as the difficulties in their creation and functioning.

\section{KEY FEATURES AND TRENDS OF DEVELOPMENT OF AGRICULTURE IN SERBIA AND BULGARIA}

Researchers (1) whose study is related to the development of agriculture in Serbia and other 
Western Balkan countries underline that in these countries, also face significant limitations in the agriculture development, like fragmented farm-holdings, low productivity, the use of outdated techniques and technology, low level of investments (caused by insufficient investment capacities and lack of interest for investments), low level of business activities, undeveloped infrastructure, low income and lack of alternative types of financing.

The development of agriculture in the Republic of Bulgaria and the Republic of Serbia shows similar processes of change. The relative share of agriculture is reduced in the formation of gross value added. For the ten-year period in Bulgaria, the decrease has led to the following changes - from $8.5 \%$ (2005) to $5.1 \%$ (2015), and in Serbia - from $12.0 \%$ (2005) to $8.4 \%$ (2015). Despite these changes, in both countries the importance of agriculture to the economy is much greater than the average values of the EU countries - 1.5 percent in 2015.

Within the first programming period of Bulgaria's membership in the EU, the economic importance of the agricultural sector in the Bulgarian economy has stabilized at 4.8 - 5\%. The share of employees in total employment remained at $19 \%$. According to Farm Accountancy Data Network favorable changes occurred in the productive and economic results of the farms. Only for 4 years (2009-2012) the total production per hectare of crop and livestock unit increases respectively with $71.8 \%$ and $38.6 \%$. The net added value per annual work unit increases with $85.3 \%$ (2). Generally positive trend of growth of gross added value created in agriculture by $11 \%$ are observed, while the value of production increased by $21 \%$ in 2014 compared to 2007 . These results are mainly due to the serious increase of plant production (59\%), reducing livestock (13\%) and continuing the trend of reducing the proportion of livestock to $28.5 \%$. In recent decades, there is undergoing processes of limiting the number of crops. In $2015-77.9 \%$ of the arable land is dominantly cultivated by four crops. Many areas are transformed to monoculture agriculture.

The negative trend in the development of livestock is the tendency of reduction in the number of animals. During the period 20072015 the highest reduction are observed in number of goats (over 44\%), pigs (over 30\%), dairy cows (18\%) and ewes (12\%). Increasing can be observed only in the number of buffaloes (20\%). Regardless of the trend of increasing the average size of herds in all livestock. The average size of the herd of dairy cows is 8.3, in ewes - 31 animals, in-goats 9.4 , etc.

The reduction in the number of animals since 2007 is largely due to the reduction of small family holdings raising up to 5 livestock units (LSU), which with the current system of farm certification is almost impossible to meet the requirements of the Common European Market. These farms either reduce the number of animals or completely cease their activities. According to the Ministry of Agriculture and Food in 2013, 1,025 million livestock units are grown on the territory of Bulgaria in 177,358 farms or an average of 5.8 LSU per farm.

Compared to Bulgaria, livestock farming is more important for the Serbian economy. According to the Census data Serbia (3) has 2.020 million livestock units (LSU). About 77.5 percent of farm holdings had some livestock. The average numbers of LSU per holding (4.1) and per hectare of UAA (0.59) suggest predominance of small herds. Almost a third of households have less than 1 LSU, indicating that livestock production is based on self-sufficiency needs. Regional differences in the average number of LSU per farm follow the pattern of land size - the smallest farms are in Southern and Eastern Serbia Region (2.9 LSU per farm), while it is highest in Voivodina Region (6.2 LSU per farm).

\section{AGRICULTURAL HOLDINGS}

Serbian agriculture is traditionally characterized by an unfavourable ownership structure, which is typical of family farms which, as the largest number of subjects in agriculture, predominantly determine its overall development (4).

Among Serbia's 631,000 agricultural holdings (Table 1) and 99.5 per cent are family farms. The average farm size is 5.4 hectares, which is 2.7 less than the European Union average. Small-scale producers are prevalent in the livestock sector. Farms of between 2 and 10 hectares make up the largest share of the country's farms while holdings of less than 1 hectare account for 29.2 per cent.

Agriculture Census from 2012 indicate that over $50 \%$ of the land used in Serbia is concentrated on the farms of 2- 20 ha. This is directly reflected in the low level of production results, which are far below those recorded in developed countries.

According to the Strategy of agriculture and rural development of the Republic of Serbia, 
DOITCHINOVA J., et al.

small family farms in Serbia make a very heterogeneous group and could be divided into several categories. The category of poor farms can be further divided to two subtypes: ageing farms which are often run by a single person, and farms owned by people who were once employed outside of agriculture and/or have been long-term unemployed.

Table 1. Distribution of agricultural holdings on used agricultural land in Serbia and Bulgaria

\begin{tabular}{|c|l|l|l|l|}
\hline \multirow{2}{*}{ Used aricultural land } & \multicolumn{4}{|l|}{ Serbia 2012 } \\
\cline { 2 - 5 } & Number of farms & Structure & Number of farms & Structure \\
\hline 0 ha & 10.107 & 1.6 & 9.549 & 3.76 \\
\hline до 2 ha & 297.748 & 47.15 & 183.643 & 72.26 \\
\hline $2-5$ ha & 182.489 & 28.9 & 27.808 & 10.94 \\
\hline $5-10$ ha & 89.083 & 14.11 & 10.881 & 4.28 \\
\hline 10-20 ha & 32.313 & 5.12 & 6.780 & 2.67 \\
\hline $20-30$ ha & 7.677 & 1.22 & 3.211 & 1.26 \\
\hline $30-50$ ha & 5.352 & 0.85 & 3.410 & 1.34 \\
\hline $50-100$ ha & 4.394 & 0.7 & 2.959 & 1.16 \\
\hline над 100 ha & 1.851 & 0.29 & 5.901 & 2.32 \\
\hline Тотаl & 631.552 & 100 & 254.142 & 100.00 \\
\hline
\end{tabular}

The next category is people 'returning' from urban areas. These are mostly older, retired people or sporadically young families which prefer rural ambience and are willing to start some alternative activity on a small agricultural farm. The third category is habitants of rural areas with regular incomes from sectors outside agriculture. These could be entrepreneurs or employees of public services or other firms in or near to the place where they live. The current potential of small rural farms in the Republic of Serbia is modest, inadequate and thus insufficiently attractive for investments.

In Bulgaria, during the transition period a decline in a total number of farms is observed. This process continues after the country's accession to the European Union. Between 2007 and 2013 the numbers of farms declined with $48 \%$. According to the data the reduction is mainly in landless farm groups and farms under 5 hectares agricultural land. Liquidated farms are more than 230000 (56\% of the total), having land up to 2 hectares. The decline happened mainly because marginal reasons, and a lot of small scale and subsistence producers left the sector (5). Even the tendency there is still farms smaller than 10 hectares and they have share above $90 \%$ of total farm numbers. The average size of Bulgarian farms is 14.93 ha (2013). During the years of EU membership it grew $241 \%$.

Bulgarian agriculture is characterizes by a dualistic structure of farms: on one hand smallscale (usually subsistence oriented) farms, and on the other large farms (agricultural enterprises). $80 \%$ of the used agricultural land is operated by $2.3 \%$ of the farms (514 ha average farm size) and $87 \%$ of the farms cultivate $4.8 \%$ of the used agricultural land. The relative share of land that is used with lease or rent contracts is very high. They reach $83 \%$, while in Serbia they are only 29.64 per cent.

There are significant differences in the size of holdings of natural and legal entities (cooperatives, companies, sole traders, associations etc.) identified in 2013. The average UAA of holdings of the natural persons in Bulgaria is only 3.4 ha. In the holdings of legal persons average managed UAA is much greater companies reached 316.4 ha, while cooperatives is 689.13 ha. Cooperatives handled $14.9 \%$ of the total UAA in farms, businesses and sole traders $51.1 \%$ of this area, and individuals $-32.2 \%$ (Table 2).

The deteriorated infrastructure for the development of small farms is due to the reduction in the number and importance of cooperatives. They provide mechanized services to the small farms in many areas.

The structure of agricultural holdings in Serbia illustrates the relatively more limited presence of agricultural holdings in legal entities with only $0.5 \%$ compared to $3 \%$ in Bulgaria.

The Serbian agricultural sector employs 1.4 million people. The total number of annual work units (AWU) in 2012 was 646,283, i.e. 1.02 per holding - from 11.7 ha of UAA per AWU in Vojvodina to 3.6 ha of UAA per AWU in southern Serbia. The average age of the farm holder is 59 years, with 35 percent of farmers over 65 years of age. 
DOITCHINOVA J., et al.

Table 2. Structure of agricultural holdings in Bulgaria (2003-2013)

\begin{tabular}{|l|l|l|l|l|}
\hline \multirow{2}{*}{ Legal status } & \multicolumn{2}{|l|}{ Number of Agricultural holdings } & Change 2013/2003 \\
\cline { 2 - 5 } & 2003 & 2010 & 2013 & $\%$ \\
\hline $\begin{array}{l}\text { Agricultural holdings - } \\
\text { total }\end{array}$ & 665548 & 371070 & 254142 & $-61,81$ \\
\hline Natural persons & 658594 & 363620 & 237317 & $-63,97$ \\
\hline Sole traders & 3072 & 2270 & 1871 & $-39,10$ \\
\hline Cooperatives & 1992 & 940 & 811 & $-59,29$ \\
\hline Companies & 1518 & 3900 & 4323 & 184,78 \\
\hline Associations & 372 & 340 & 272 & $-26,88$ \\
\hline
\end{tabular}

In Bulgarian agriculture are employed 0.557 million people. With a total number of 320231 AWU their average number per holding is 1,26. $29 \%$ of employees are over 65 years of age.

\section{Problems of setting up and functioning of network structures of small farmers}

The network is the place, where the members from one or different sectors work together and add value to the product marketed. In the context of agricultural policy implementation, the term "network policy" refers to provision of institutional incentives for companies in the sector to act as a competitive industrial framework. In the presence of high concentration of small agricultural companies it is interesting how they appear to be competitive in terms of quality, production costs and price. The answer is in their ability to behave as part of a group, binding together on the base of produced product or geographical region and benefiting from their common competitive advantage in terms of specialization, cooperation and flexibility. Due to diversity of characteristics and dynamics' level of its rural regions, still the most important aspect for networks is the better accumulation of resources - both institutional and financial, is the degree of technological innovation, capital investment opportunity, intensification of production process, level of competitiveness and environmental undertakings.

The economic literature is definitive towards the benefits that individual farmers acquire from being a member of producer organization $(6,7)$. By pooling their agricultural output farmers may: strengthen their bargaining power vis-à-vis potential buyers ("downstream") and input suppliers ("upstream"); reduce risks, typical for farming activities; benefit from economies of scale; reduce the average fixed cost associated with the investment, and reducing transaction costs by pooling their output.
Finally, in addition to the above mentioned benefits, that lead to higher incomes for the members of the producer organizations compared to a situation where farmers act individually, there are also a number of intangible benefits associated with the membership in a producer organization, such as improving social cohesion, partnership and trust among its members and the development of specific skills, such as the ability to resolve conflicts and reconcile individual interests.

Farmers' organizations are not widespread in Bulgaria and Serbia regardless of the numerous advantages and opportunities. According to Bogdanov and Rodić (8), the food chain in Serbia is currently very fragmented and insufficiently organized in both production and processing. A large part of the agricultural sector is not integrated into agro-food supply chains, either by contracting or by any other means of commercial relationships. This especially refers to the large group of small scale farmers and a large number of small processing units, whose position is critical as they have to comply with the requirements of an increasingly demanding retail chain.

The main reason for the limited distribution of networks within the Bulgarian agribusiness and rural areas, according to the experts (participated in a survey in 2016) is the lack of trust between farmers, processors and traders (89\%). This is largely predetermined by the specific development of agribusiness in Bulgaria over the last 25 years of broken links between production, processing and marketing, as well as the broken tradition of private farming. Higher requirements for volume of sales and administrative procedures of the SAPARD program for rural development (2007-2013), also referred to as a reason for the low level of motivation of farmers to set up producer organizations, associations and others. This is the opinion of $73.7 \%$ of respondents. Similar opinion of the experts raises questions about the quality of the criteria 
used to finance network structures - whether they are suitable for the conditions of Bulgarian agriculture and why it had to be cut several times in recent decades. Like other reasons are shown indifference to the relatively large agricultural producers, processors and traders (57.9\%) and insufficient awareness of producers in rural areas.

Similar results are shared by farmers - the producers of cherries (9). Respondents were 82 farmers who are 32 percent of all farms with cherry trees in Kyustendil area.

Extremely large majority of respondentproducers $(94 \%)$ do not participate in network structures. Among the main reasons is the fact that they are not aware of the opportunities and benefits of network structures (40\%) and that the area in which their holdings are situated - is not covered by a network organization (39\%). The main reason why in Bulgaria network structures are not distributed highlights the lack of trust between the producers (94\%).

Regarding the expected benefits (Table 3) the highest are the estimates signifying that participation in the network will increase incomes (average grade 4.12) and improve the market for production (4.06) and will facilitate access to international markets (4.0). The highest assessment is 5 .

These results suggest that the benefits of membership in the network structures are known and appreciated by the potential participants, but $65 \%$ of respondents prefer to join them at a later stage after obtaining evidence of good performance of the organization.

Table 3. Assessment of the benefits of network structures

\begin{tabular}{|l|l|}
\hline Benefits & Assessment \\
\hline $\begin{array}{l}\text { Participation in the network will improve the opportunities for } \\
\text { commercialization of production }\end{array}$ & 4,06 \\
\hline $\begin{array}{l}\text { Participation in the network will lead to an increase in the quality and } \\
\text { quantity of production }\end{array}$ & 3,85 \\
\hline $\begin{array}{l}\text { Participation in the network will contribute to better performance of } \\
\text { agro-technical activities }\end{array}$ & 3,91 \\
\hline $\begin{array}{l}\text { Participation in the network will facilitate access to European and } \\
\text { international markets }\end{array}$ & 4 \\
\hline Participation in the network will reduce business risk. & 3,82 \\
\hline Participation in the network will increase the income of farmers & 4,12 \\
\hline $\begin{array}{l}\text { The network will increase the competitiveness of our region and } \\
\text { investment }\end{array}$ & 3,99 \\
\hline
\end{tabular}

\section{Opportunities, guidelines and recommendations}

The Ministry of Agriculture and Environmental Protection in Serbia is paying special attention to the development of small family farms. These farms enable the establishment of a sustainable development system and significantly contribute to the preservation of rural areas, as well as keeping the population, especially young people, in the countryside. Therefore the ministry has recently adopted the Strategy of Agriculture and Rural Development 2014-2024 of the Republic of Serbia (10). The main strategic goals of this strategy are the growth of production and income stability; growth of competitiveness with adjustments to the requirements of domestic and foreign markets and technical-technological promotion of the sector; sustainable management of resources and environment protection; promotion of quality of life in rural areas and poverty reduction; efficient management of public policies, and the promotion of an institutional frame for agricultural and rural development.

An important part of the Programme for Rural Development is dealing with the diversification of rural activities, aiming to lessen poverty in small farms by broadening their activities and engaging all resources towards increased employment of members of these farms. Currently there is an intense concurrency of agricultural products, not only on the national market but also on the global market. According to the number of traditional agricultural and food products, Serbia is among the countries with a significant number of Protected Geographical Indication (PGI) products. Therefore the Ministry of Agriculture and Environmental Protection is focusing its activities on increases in production and the inclusion of a larger number of producers in the production of traditional products with the Protected Designation of Origin (PDO) or PGI label. Being aware of the fact that it is dealing 
DOITCHINOVA J., et al.

with small producers, the ministry has adopted the Law on Incentives in Agriculture and Rural Development, which foresees subsidies for small farmers. Producers of traditional agricultural and food products with the PDO/PGI label will receive additional subsidies for control and certification of their products as well as for labelling their products with control stamps.

The strategic approach of the Programme for Rural Development will define developmental concepts, especially multifunctional rural development, promoting the functionality of rural areas, the significance of the preservation of natural habitat and biodiversity, ethnoambience and so on - all of which make small family farms an important developmental force in rural areas. With all the aforesaid, it would be fair to say that one of the priorities of the Strategy for Agriculture and Rural Development of the Republic of Serbia 20142020 and National Programme for Rural Development is to support Serbia's traditional food production as one of the main forces of rural development.

The Programme for Rural Development of the Republic of Bulgaria 2014-2020 contains a number of measures and incentives for the development and strengthening of small farms. Moreover, a special thematic sub-program was developed, which includes two types of measures:

1. Measures that are specific to the subprogram and only small farms may apply for them: consultancy services, management services and substitution services; Investments in tangible assets; Development of farms and enterprises.

2. Measures involving specific components or priorities targeted at small farms: Transfer of knowledge and awareness actions; - Creation of producer groups and organizations; Collaboration.

The second group of measures is going to be implemented under the main program in order not to complicate the control of the implementation of the RDP and to not stop the union of small farms with other farmers and the construction of territorial or sectoral producer networks.

Especially important for the development of small farms in both countries have joint activities in the field of realization of products, supplies of raw materials and other activities of common interest.
The establishment of a variety of network structures based on cooperation and collaboration can not only contribute to strengthening the capacity of small farms and increasing the incomes of their farmers, but also to sustainable rural development.

\section{ACKNOWLEDGMENTS}

The research leading to these results has received funding from the People Programme (Marie Curie Actions) of the European Union's Seventh Framework Programme FP7/20072013/ under REA Grant Agreement No. 611490 (PIAPP-GA-2013-611490).

\section{REFERENCES}

1. Stojadinović Jovanović, S., Dašić, B., The importance of foreign direct investment for South East European countries' agriculture, Economics of agriculture, vol. 62, no. 3., pp. 661-676, 2015.

2. Ministry of Agriculture and Food, The Programme for Rural Development of the Republic of Bulgaria 2014-2020.

3. Ministry of Agriculture and Environmental Protection of Republic of Serbia (2014) Agriculture in the Republic of Serbia in 2013

4. Munćan D.and Boţić P., Family farms - the factors of agricultural development in Serbia, 100 th Seminar EAAE, 2007.

5. Harizanova, H., Economic results agricultural activities of the semisubsistence farms in Bulgaria, Management and sustainable development, 3-4, 251-255, 2010.

6. Williamson, O., Reflections on the new institutional economics, Journal of Institutional and Theoretical Economics, $v$. 141, N 1. (б), 1985.

7. Zaimova, D., Cooperative models in the agricultural sector. Development perspectives and solutions across Europe (Italy and Bulgaria), LAP Lambert Academic Publishing, Germany, 2011.

8. Bogdanov, N., Rodić V., Agriculture and Agricultural Policy in Serbia, edit. Volk, T., Erjavec, E. and Mortensen, K. Agricultural Policy and European Integration in Southeastern Europe, FAO, 2014.

9. Terziyska, R., Opportunities and effects of setting up organization of cherries producers in the Kyustendil region, Conference proceedings: Agribusiness and Rural Areas - present and future development, 212-219 pp, Varna 2015.

10. Ministry of Agriculture and Environmental Protection ,Strategy of Agriculture and Rural Development 2014-2024 of the Republic of Serbia 